\title{
IMPLEMENTASI TURNITIN UNTUK MEMAKSIMALKAN ORISINALITAS KARYA ILMIAH DI JURUSAN AQIDAH FISAFAT ISLAM IAIN TULUNGAGUNG
}

\author{
Lia Umaroh
UIN Sayyid Ali Rahmatullah Tulungagung \\ Email: Liauma18@gmail.com \\ Teguh \\ UIN Sayyid Ali Rahmatullah \\ Email: muhammad.teguh.ridwan@gmail.com
}

\begin{abstract}
Abstrak:
Implementasi turnitin belum bisa memaksimalkan orisinalitas karya ilmiah mahasiswa Akidah Filsafat Islam. Masih ditemukan beberapa karya dengan tingkat similarity tinggi meskipun sudah dilakukan sering dilakukan pelatihan kepenulisan dan pengecekan karya dengan turnitin. Penelitian ini bertujuan menjelaskan implementasi turnitin untuk memaksimalkan orisinalitas karya ilmiah di jurusan Akidah Filsafat Islam IAIN Tulungagung. Metode yang digunakan dalam penelitian ini adalah kualitatif deskriptif. Sedangkan teknik pengumpulan data dimulai dari observasi partisipan pencarian dokumen hingga wawancara secara mendalam. Pada tahap analisis data penulis melakukan tiga tahapan yang meliputi reduksi data, display data dan penarikan kesimpulan. Hasil penelitian menunjukkan bahwa Pada tahap formulasi perpustakaan pusat IAIN Tulungagung juga memiliki peran penting dalam pemberian pelatihan turnitin. Kemudian tahap pelaksanaan akses turnitin didapatkan secara langsung dari perpustakaan dan hanya ada seorang instruktor saja tanpa adanya sebuah kelas student dalam akses turnitin. Sedangkan tahap evaluasi disebutkan masih adanya mahasiswa yang karyanya memiliki jumlah similarity yang masih tinggi meskipun sudah diadakan beragam pelatihan menulis.
\end{abstract}

Kata kunci : Implementasi Turnitin, Orisinalitas, Plagiarisme, Skripsi.

\begin{abstract}
:
The implementation of turnitin has not been able to maximize the originality of the scientific works of Islamic Philosophy students. There are still several works with a high level of similarity, although writing training is often carried out and checking works with turnitin. This study aims to explain the implementation of turnitin to maximize the originality of scientific works in the Islamic Philosophy Department of IAIN Tulungagung. The method used in this research is descriptive qualitative. Meanwhile, the data collections technique starts from participant observation to search for documents to in-depth interviews. At the data analysis stage, the writer carried out three stages which included data reduction, data display and conclusion drawing. The results showed that at the formulation stage the central library IAIN Tulungagung also had an important role in providing turnitin training. Then the implementation stage of turnitin access is obtained directly from the library and there is only one instructor without a student class in turnitin access. Meanwhile, in the evaluation stage, it is stated that there are still students whose works have a high similarity even though various writing trainings have been held.
\end{abstract}

Keywords : Turnitine Implementation; Originality; Plagiarism; Scientific Work.

\section{Pendahuluan}

Perkembangan pendidikan dalam dunia perguruan tinggi, akan mengalami kemajuan yang semakin pesat. Dengan ditandai munculnya beragam bentuk karya tulis, yang memiliki tingkat orsinalitas yang baik. Karya ilmiah merupakan sebuah tulisan yang memuat tentang kajian- kajian dalam sebuah permasalahan yang tertentu, dimana dalam penulisannya tentunya menggunakan kaidah kaidah yang sudah ada dan sudah ditentukan. Dalam Peraturan Kepala Badan Kepegawaian Negara No 49 Tahun 2015 dijelaskan bahwa:

Karya tulis/ karya ilmiah berupa sebuah tinjauan atau ulasan ilmiah dari gagasan sendiri di bidang penilaian kompetensi manajerial yang 
tidak dipublikasikan maupun disampaikan dalam pertemuan ilmiah atas inisiatif sendiri.

Penulisan sebuah karya ilmiah tentunya akan ada pengutipan, baik teori, ide maupun gagasan dari sumber lainnya baik secara langsung maupun tidak langsung. pengutipan tersebut harus disertai dengan adanya perujukan guna menghindari pelanggaran pelanggaran yang ada dalam etika penulisan karya tulis ilmiah. Pelanggaran itu sering disebut dengan tindak plagiarisme, kegiatan baik dengan sengaja maupun tidak sengaja dengan pengambilan karya orang lain. Kebiasaan plagiarisme merupakan pelanggaran hukum, hal ini juga sudah diatur dalam pasal 1 ayat (1) Peraturan Mentri Pendidikan Nasional Nomor 17 Tahun 2010 Tentang Pencegahan Dan Penanggulangan Plagiat Di Perguruan Tinggi:

Plagiat adalah perbuatan sengaja atau tidak disengaja dalam memperoleh atau mencoba memperoleh kredit atau nilai untuk suatu karya ilmiah, dengan mengutip sebagian atau seluruh karya dan atau karya ilmiah pihak lain yang diakui sebagai karya ilmiahnya, tanpa menyatakan sumber secara cepat dan memadai.

Tindak plagiarisme inilah yang akan mengurangi orsinalitas sebuah karya tulis mahasiswa. Karya tulis baik merupakan suatu karya yang mengikuti kaidah maupun etika penulisan yang ada dan ditentukan. Dengan keberadaan Karya tulis, juga dilindungi oleh undang undang mengenai hak cipta, yang tercntum dalam Undang Undang Hak Cipta Nomor 28 Tahun 2014 Dalam Pasal 40 Ayat (1) menjelaskan mengenai ciptaan yang dilindungi di bidang ilmu pengetahuan, seni dan sastra terdiri dari 19 poin diantaranya adalah karya tulis berupa buku, perwajahan karya tulis

1Steven Yehezkiel Sinaga, Penggunaan Aplikasi Turnitine Sebagai Sarana Cek Plagiarisme Dalam Layanan Perpustakaan Ukrida, diakses dari http//:journal2.um.ac.id

${ }^{2}$ Yonhatan C. M dan Lidya Cristiani, Pemanfaatan Sistem Deteksi Plagiarisme Menggunakan Turnitin Pada Jurnal Mahasiswa Universitas Dian Nuswantoro, diakses dari https://ejournal3.undip.ac.id

${ }^{3}$ Direktur Jendral Pendidikan Islam, Keputusan Direktur Jendral Pendidikan Islam Nomor 7142 Tahun 2017 Tentang Pencegahan Plagiarisme di Perguruan Tinggi Keagamaan Islam. yang diterbitkan, dan hasil karya tulis lainnya.

Berkembangnya ilmu pengetahuan dan teknologi yang semakin pesat mulai muncul berbagai aplikasi open sources yang mampu membantu meningkatkan dalam orsinalitas sebuah karya. Aplikasi tersebut seperti plagium, plagiarism checker, viper dan sebagainya. Turnitin juga merupakan aplikasi cek orsinalitas karya tulis yang sifatnya berbayar dan diciptakan oleh iParadigms, LLC. Turnitin ini pertama kali launching pada tahun 1997 yang mana mampu menghubungkan antara dosen dan mahasiswa melakukan scanning pada sebuah karya ilmiah. Namun pada awalnya, aplikasi turnitin diciptakan oleh Dr. John Barrie yang berasal dari University Of Berkeley, California dengan tujuan mempermudah identifikasi plagiarisme dalam karya tulis akademik dengan identifying dan comparing, selain itu meskipun banyaknya beragam aplikasi yang bermunculan , turnitin mulai menjadi aplikasi yang popular dan walaupun mendapatkan berbagai kritik, turnitin sudah dianggap sudah berguna karena aplikasi ini juga menyertakan report atau laporan indikasi plagiat, yang berguna untuk bagian mana yang harus diperbaiki ${ }^{1}$.

Turnitin ini mulai berkembang dan digunakan di Indonesia khususnya di berbagai perguruan tinggi negeri, sebab munculnya berbagai tindak plagiarisme dalam pembuatan karya ilmiah. Deteksi turnitin yang berbasis web merupakan salah satu aplikasi yang memberikan efektivitas terhadap peningkatan orisinalitas karya, hal tersebut disebabkan jangkauan turnitin yang berasal dari berbagai sumber literatur dan turnitin mampu mendeteksinya, hal ini dituliskan dalam sebuah jurnal karya Walchuk tahun 2016"As part of a study on the plagiarism detection progams turnitin and My DropBox, sourced computer science

\footnotetext{
${ }^{4}$ Khairul Anam, Tutorial Cek Plagiasi dengan Turnitin,(2017).

${ }^{5}$ Turnitine LCC, (2018b), diakses dari www.turnitine.com.

${ }^{6}$ Aan Prabowo, Peran Pustakawan Dalam Literasi Layanan Turnitine Kepada pemustaka di Universitas Dian Nuswantoro, Diakses dari https:// ejournal.undip.ac.id

${ }^{7}$ Wawancara MC, 05 November 2020.
} 
liteature downloaded from a pasword protected publisher's website and submitted the papers without modification to both progams".

Pada penelitian disertasi karangan Terence Brennan tahun 2015 yang berjudul "The Effect Of Turnitin.Com On Non Traditional, Graduate Student Awarreness, Behavior And Trust" menjelaskan bahwa turnitin terkoneksi dengan satu juta universitas dan 20 juta mahasiswa di 126 negara, dengan perkembangan lebih dari 250 juta karya ilmiah. Database karya ilmiah turnitin selalu bertambah 190,000 judul setiap harinya. Diketahui dari data yang diambil dari turnitin, juga diketahui bahwa turnitin memiliki licensed untuk terkoneksi dengan 24 milyar website yang ada di internet ${ }^{2}$. Kemampuan itu yang mampu membantu dosen dalam memberikan penilaian terhadap orsinalitas sebuah karya mahasiswa terutama dalam pengecekan ulang similaritas karya tulis.

Dalam penggunaanya turnitin merupakan online web yang dapat diakses secara premium oleh sebuah perguruan tinggi dengan harga yang sudah disepakati antar keduanya. Batas toleransi dalam pembuatan karya ilmiah atau skripsi yang berbasis aplikasi deteksi plagiarisme, yang digunakan sebagai persyaratan kelulusan pada jenjang D-4 atau progam sarjana maksimal $25 \%^{3}$. Dari kutipan Belinda berdasarkan pada tulisan Pavati Iyer mengenai Document Similarity Analysis for a Plagiarism Detection System, bahwa terdapat beberapa tipe plagiarisme yaitu plagiarisme ide, plagiarisme kata demi kata, plagiarisme atas sumber dan plagiarisme kepengarangan.

Aplikasi turnitin ini sudah banyak digunakan oleh berbagai perguruan tinggi, salah satunya yakni jurusan Akidah dan Filsafat Islam (AFI)

${ }^{8}$ Turnitin LCC, The Effectiveness of Turnitine in Higher Education, diakses dari http://go.turnitinecompaper

IUlpah Andayani, Penggunaan Softwere Turnitin untuk Mendeteksi Tindakan Plagiarisme, diakses dari http://journal.uin.jkrt.ac.id .

${ }^{10}$ Direktur Jenderal Pendidikan Islam, Keputusan Direktur Jenderal Pendidikan Islam Nomor 7142 Tahun 2017 Tentang Pencegahan Plagiarisme di Perguruan Tinggi Keagamaan Islam.
IAIN Tulungagung. Penggunaan turnitin pada AFI juga digunakan dalam pengecekan orsinalitas sebuah karya tulis yakni skripsi. AFI ini didirikan sudah cukup lama sejak tahun 2009, jurusan yang terbilang berdiri sejak awal kampus IAIN Tulungagung ada. Sejak dahulu jurusan ini sudah mengembangkan berbagai aktivitas tentang dunia kepenulisan dan sampai sekarang masih terbilang masih eksis.

AFI juga merupakan salahsatu jurusan yang juga senatiasa menghimbau mahasiswanya mampu memiliki keunggulan dalam kajian islam jawa, mampu mengembangkan keilmuan dan penegasan identitas islam jawa demi transformasi masyarakat, yang disuguhkan dalam berbagai bentuk karya tulis skripsi dan jurnal. Sedangkan pada jurusan AFI skripsi yang telah dibuat juga akan disubmit pada beberapa jurnal yang sudah terindeks. Keaktifan dalam pemberian diklat, pelatihan maupun pembelajaran tentang penulisan karya ilmiah juga kerap kali dilaksanakan, Namun masih adanya mahasiswa yang tingkat similarity nya tinggi. Selain itu penggunaan turnitin belum dilakukan secara baik karena dalam akunnya masih terbilang tidak aktif. Maka dari itu peneliti berkeyakinan, terdapat masalah yang lebih kompleks dalam judul penelitian, sehingga penelitian ini bertujuan untuk menjelaskan bagaimana implementasi turnitin untuk memaksimalkan orisinalitas karya ilmiah di jurusan Aqidah Filsafat Islam IAIN Tulungagung.

Terdapat juga beberapa penelitian terdahulu yang menjelaskan tentang implementasi turnitin untuk pencegahan plagiarisme, pemanfaatan turnitin sebagai deteksi plagiarisme. Sedangkan perbedaan dengan penelitian sekarang terletak pada Implementasi dari turnitin itu sendiri. Penelitian

\footnotetext{
${ }^{11}$ Wawancara AF, 05 November 2020.

${ }^{2}$ Steven Yehiezkiel Sinaga, Penggunaan Aplikasi Turnitin Sebagai Sarana Cek Plagiarisme Dalam Layanan Perpustakaan Universitas Ukrida, diakses dari http://ejournal.um.ac.id.

${ }^{13}$ Kuncoro G Pambayun, Menganalisa Hasil Pemeriksaan Turnitin untuk Dosen Pembimbing LA/Skripsi Praja IPDN, diakses dari http://ib.pdn.ac.id.

${ }^{14}$ Russel K Baker dkk, An Evaluation Of The Effecttiveness Of Turnitine Com As A Tool For Reducing Plagiarism In Graduate Student Trem Papers.
} 
yang penulis lakukan lebih fokus untuk memaksimalkan orsinalitas karya tulis khususnya skripsi pada sebuah jurusan.

\section{Tinjauan Pustaka}

Dalam Tinjauan pustaka tentunya akan menjadi pembedah bahwa adanya referensi yang dijadikan sebagai acuan beberapa istilah maupun masalah yang terdapat studi literaturnya. Untuk menelaah tentang teori implementasi terdapat pada penelitian ataupun buku karangan Nurdin Usman yang berjudul tentang "Konteks Implementasi Berbasis Kurikulum". Selain itu penulis juga menggunakan buku karangan Wina Sanjaya dengan judul "Perencanaan dan Desain Sistem Pembelajaran" dan buku karangan Kokom Komala Sari dengan judul "Pembelajaran Kontekstual: Konsep dan Aplikasi". Kemudian juga terdapat beberapa penelitian terdahulu yang yang dijadikan sumber referensi dan menjadi pembeda antara penelian sekarang dan penelitian yang sudah dilakukan. Sedangkan perbedaan penetian terdahulu dan sekarang terletak pada Implementasi dari turnitin itu sendiri yang meliputi formulasi, pelaksanaan dan evaluasi. Penelitian yang penulis lakukan lebih fokus pada peningkatan orsinalitas karya tulis khususnya skripsi pada sebuah jurusan, kemudian pada penelitian ini dosen juga dapat menjadi fasilitator yang memberikan arahan kepada mahasiswa untuk meningkatkan orsinalitas sebuah karya ilmiah terutama skripsi.

\section{Metode Penelitian}

Metode yang digunakan dalam penelitian ini adalah kualitatif deskriptif. Sedangkan pendekatan yang dilakukan peneliti, yakni melalui pendekatan kualitatif. Artinya data yang dikumpulkan dalam penelitian bukan berupa angka, tetapi data yang didapatkan dari hasil wawancara, catatan lapangan, maupun dokumentasi

${ }^{15}$ Kuncoro G Pambayun, Menganalisa Hasil Pemeriksaan Turnitin untuk Dosen Pembimbing LA/Skripsi Praja IPDN, diakses dari http://ib.pdn.ac.id. pribadi. Menurut Bogdan dan Taylor dalam buku Moleong, metode kualitatif adalah prosedur penelitian yang menghasilkan data deskriptif berupa kata-kata tertulis atau lisan dari orang-orang dan perilaku yang dapat diamati yang diarahkan pada latar dan individu secara holistic (utuh).

Dalam penelitian kualitatif ini peneliti dijadikan sebagai instrument kunci dalam memberikan pengaruh terhadap kegiatan penelitian. sebab hanya seorang peneliti yang mampu menilai kenyataan di lapangan serta dapat mengatasi masalah yang ada di lapangan hal tersebut dituluskan dalam buku karangan Moleong. Penelitian ini akan dilakukan di jurusan Akidah Filsafat Islam IAIN Tulungagung dengan beberapa subjek penelitian antara lain dosen, mahasiswa dan pustakawan, kemudian untuk objek penelitian difokuskan pada implementasi turnitin pada karya ilmiah jurnal dan skripsi. Dalam penyusunannya peneliti akan menyajikan secara naratif dimana dengan didukungnya berbagai sumber sumber penguat data yang diperoleh dari penelitian.

Peneliti dalam melakukan pengumpulan data menggunakan wawancara mendalam serta dokumentasi. Sedangkan Teknik analisis data yang dilakukan bisa dimulai dengan observasi partisipan (mengamati aktivitas yang dilakukan dalam tahap implementasi turnitin secara berkala dari waktu ke waktu dalam kurun tiga kali), pencarian dokumen (terhadap administrator turnitin IAIN Tulungagung dan instructor turnitin jurusan AFI) hingga wawancara secara mendalam (wawancara kepada 9 informan diantaranya pustakawan, kajur, dosen dan mahasiswa).

Tahapan analisis yang digunakan dalam penelitian ini, peneliti menggunakan tahapan model analisis Miles dan Heuberman yang meliputi tiga kegiatan, yaitu tahap reduksi data (melakukan penyederhanaan data yang diperoleh), display data(menyajikan data dari tahapan implementasi secara sistematis) dan penarikan sebuah kesimpulan (mendapatkan hasil dan kesimpulan yang sesuai dengan permasalahan). Peneliti melaku- 
kan observasi dan pengamatan secara berkelanjutan sejak tanggal 05 November - 10 Desember 2020. Adapun teknik pengecekan keabsahan data, penulis menggunakan metode trianggulasi Selain itu untuk melakukan pengecekan keabsahan data, penelitian ini didasarkan pada tiga kriteria yang meliputi kepercayaan, kebergantungan dan kepastian.

\section{Hasil dan Pembahasan}

Formulasi Turnitin Dalam Peningkatan Orsinalitas Skripsi

Tahapan awal atau formulasi dalam implementasi turnitin di jurusan Akidah Filsafat Islam seringkali menggunakan Alur logika dalam sebuah penelitian. Pada dasarnya sebuah karya ilmiah sebelum dimasukkan dalam sistem deteksi plagiarisme atau turnitin akan mudah terlihat dari mulai penyusunan kata dan kalimat. Namun hal tersebut hanya berlaku bagi para dosen, akademisi maupun peneliti yang kerap bergulat di bidang penelitian maupun penulisan karya ilmiah, sehingga mereka akan dapat dengan mudah mendeteksi tindak plagiat. Namun jarang sekali pada zaman teknologi ini para dosen dan akademisi dapat melakukan hal tersebut dengan cara manual, mereka akan lebih banyak menggunakan berbagai macam softwere deteksi plagiarisme seperti turnitin.

Tanpa disadari penggunaan turnitin juga mengabaikan aspek aspek kepekaan seorang mentor maupun penguji dalam melihat kualitas tulisan, mulai dari konten, sistematika dan logika. Aplikasi turnitin itu sendiri akan dapat memberikan presentase maupun tingkat kesamaan yang biasanya bergariskan warna yang terdapat pada setiap kolom similarty. Adapun catatannya adalah bahwa prosentasi yang ada tidak selalu menunjukkan tingkat plagiasi sebuah artikel dikarenakan bisa jadi sistem memasukkan daftar pustaka dalam pemeriksaannya, maka untuk memastikan yang perlu dilihat adalah mana saja tingkat kesamaannya kemudian dihitung ${ }^{4}$. Pengurangan tindak plagiarisme itu sendiri dapat dilakukan menggunakan kutipan maupun paraphrase, perbedaannya antara lain jika paraphrase merupakan kegiatan menulis ulang dengan makna sama dengan bentuk yang berbeda sedangkan kutipan adalah menulis ulang dengan bentuk yang sama maka keduanya harus tetap mencantumkan berbagai referensi yang sudah digunakan dalam penulisan sebuah argument maupun pendapat.

Formulasi merupakan sebuah tahapan awal yang digunakan untuk menyusun berbagai perencanaan hingga terjadi sebuah kinerja secara baik dan mendapatkan hasil secara maksimal. Tahap ini tentu akan dilakukan oleh berbagai lembaga organisasi maupun sebuah institusi untuk menjalankan setiap tugasnya. Sedangkan dalam formulasi turnitin itu sendiri, lembaga menyiapkan beberapa konsep dan rancangan dalam deteksi, baik mulai dari admin, softwere aplikasi maupun dokumen perangkat lain yang berhubungan dengan penggunaan deteksi plagiarisme yakni turnitin.

Tahapan formulasi juga dilakukan oleh perpustakaan pusat IAIN Tulungagung. Dimana salah satu pustakawan di perpustakaan menjadi administrator, yakni yang bertugas memberikan akses turnitin dan mengelola database dalam turnitin. Untuk mengoptimalkan penggunaan turnitin perpustakaan pusat sudah melakukan upaya edukasi yang diselenggarakan pelatihan terhadap penggunaan turnitin hingga pemberian soft file modul kepada semua instructor. Dengan pemberian modul semua instructor dapat memanfaatkan akses turnitin yang sudah diberikan dengan baik dan maksimal.

Sebelum menggunakan sistem deteksi plagiarisme turnitin ini hendaknya setiap pengguna, harus memahami modul yang telah disediakan, adapun macam macam modul tersebut antara lain:
a. Originality Check
b. Grade Mark Digital
c. Peer Mark
d. Grade Book ${ }^{5}$ 
Sidik dokumen sepenuhnya memiliki sebuah keunikan yang dapat diidentifikasi oleh salah satu fitur yang dapat ditampilan dalam cetakan ${ }^{6}$. Setiap karya ilmiah tentu memiliki sebuah keunikan tersendiri, baik dari segi bahasa, gaya dan sebagainya. Sebelum menjalankan aplikasi turnitin tentu jurusan Aqidah Filsafat Islam menyediakan berabagai keperluan untuk perlengkapan dalam deteksi turnitin. Dalam pelaksanaan sistem deteksi turnitin ini jurusan AFI maupun IJIR hanya menggunakan satu admin atau satu instructor? Turnitin merupakan sebuah sistem deteksi baru dalam pendidikan yang terdapat pembagian peran dalam pelaksanaannya, penggunaan turnitin dapat dikelompokkan menjadi tiga kelompok antara lain:

a. Administrator, yakni dari pustakawan perpustakaan pusat IAIN Tulungagung.

b. Instructor, seseorang yang diberikan wewenang untuk akses turnitin dan memberikan bantuan terhadap student, seperti kajur, dosen, ataupun lembaga lainnya dilingkup civitas academica IAIN Tulungagung.

c. Student, pengguna turnitin dalam sebuah kelas kelas seperti mahasiswa.

Turnitin adalah salah satu aplikasi deteksi plagiarisme yang tentu banyak digunakan oleh berbagai perguruan tinggi salah satunya juga IAIN Tulungagung. Pada dasarnya turnitin ini dapat mengecek tingkat keorisinalitasan sebuah karya ilmiah. Aplikasi ini dapat menjadi sebuah pengaman bagi karya yang akan diterbitkan maupun karya yang sudah diterbitkan di lingkup civitas akademica IAIN Tulungagung. Berdasarkan hasil penelitian yang telah dilakukan, efektifitas penggunaan penggunaan aplikasi turnitin selama 5 tahun terakhir menyentuh angka $39 \%$, sedangkan penelitian dilakukan terhadap 55 juta karya mahasiswa dari 1003 perguruan tinggi di Amerika Serikat menunjukkan bahwa penggunaan aplikasi ini telah membantu menurunkan tingkat ketidak aslian suatu karya hingga $39 \%$ selama kurun waktu 5 tahun. ${ }^{8}$

\section{Pelaksanaan Turnitin dalam Peningkatan Orsinalitas Skripsi}

Aplikasi turnitin merupakan sistem deteksi anti plagiarisme yang berbasis web, dimana dalam akses dan penggunaanya secara berbayar maupun berlanggan. Untuk berlanggan softwere turnitin ini sama halnya dengan berlanggan database sebuah jurnal elektronik, penggunaanya sudah disesuaikan dengan masa kontrak yang sudah saling disepakati antar pengguna. Saat lembaga institusi sudah berlanggan maka mereka akan dapat mengakses turnitin dengan ID, password dan username yang diberikan. Berdasarkan hasil pengamatan penulis, tentang penggunaan turnitin sama hal nya dengan IAIN Tulungagung mereka sudah berlanggan dengan aplikasi turnitin ini. Kemudian untuk bisa akses ke berbagai jurusan maupun lembaga, admin database turnitin (administrator) membuat cabang dan ID, username dan password untuk pengguna lainnya, bisa dosen, jurusan, lembaga seperti LP2M, IJIR, LSQH, Perpustakaan setiap fakultas, perpustakaan pusat maupun lembaga lainnya di lingkup civitas akademika IAIN Tulungagung.

Deteksi Plagiarisme atau turnitin itu sendiri dilanggan secara langsung oleh UPT Perpustakaan Pusat IAIN Tulungagung, sehingga perpustakaan menyediakan akses ke berbagai lembaga yang ada dilingkungan civitas academica yang mana salah satunya adalah jurusan Aqidah Filsafat Islam dan lembaga IJIR. Pendistribusian deteksi turnitin juga dilakukan terhadap para dosen. Sedangkan dalam akses pengecekan karya ilmiah skripsi itu dilakukan langsung oleh para kajur maupun sekjur yang mana sudah diberi wewenang oleh perpustakaan pusat. Sedangkan administrator utamanya adalah salah satu seorang pustakawan di perpustakaan pusat IAIN Tulungagung. Deteksi turnitin itu sendiri juga digunakan oleh perpustakaan pusat dalam pengecekan karya penelitian dan berbagai artikel dari dosen ataupun pegawai lainnya yang akan diterbitkan.

Administrator utama mempunyai cakupan 
hak yang luas, berbeda dengan administrator yang kedua (instructor) seperti dosen dan lembaga, mereka hanya dapat menggunakan secara berkelas dan hanya untuk akses mengawasi prosentase dan tingkat kesamaan pada tindak plagiarisme mulai dari masuk pengecekan karya mahasiswa dalam suatu kelas hingga melihat hasilnya. Adapun penggunaan turnitin dalam jurusan Aqidah Filsafat Islam juga sudah diberikan panduan tata cara untuk instructor oleh perpustakaan pusat IAIN Tulungagung meliputi:

a. Membuka alamat url Turnitin (www. Turnitin. com)

b. Log in dengan username ataupun pasword yang sudah dibuat

c. Jika sebagai seorang instrukctor dapat membuka kelas dengan klik "add class"

d. Kemudian membuka assigment, dengan memasukkan assigment title (jenis artikel) dan menentukan post date sesuai dengan keinginan.

e. Untuk melakukan pengecekan similarity bisa klik bagian "more actions" lalu submit. Isilah terlebih dahulu nama depan dan nama belakang penulis, judul artikel dan letak asal artikel yang akan disubmit

f. Kemudian klik confrim

g. Hasil pengecekan similarity akan nampak. Untuk penjelasan nya angka similaryt akan menunjukkan kesamaan antara paper yang diuplod dengan sumber yang ada di internet. Dengan kategori blue (no matching words), green (one matching words-24\% similarity index), yellow (25-49\% similarity), orange (50$74 \%$ similarity), red (75-100\% similarity).

h. Kemudian untuk hasil pengecekan dapat diliahat pada document viewr frame, mulai dari mengaktifkan skala dan similarity, memberikan coment hasil pengecekanmelihat skala penilaian, melihat prosentase kesamaan sumbernya, melihat sumber danpengecualian sumber pembanding, melakukan filter terhadap paper, hingga export laporan hasil pengecekan similarity ke pdf.
Aplikasi pendeteksi plagiarisme hadir guna mengurangi berbagai tindak kejahatan dalam dunia kepenulisan. Beragam lembaga institusi dan penelitian sudah banyak menggunakan beragam aplikasi. Perangkat deteksi plagiarisme ini dapat mendeteksi teks teks suatu karya yang diduga memiliki kesamaan dengan teks teks lainnya, dan menghitung tingkat kesamaan teks tersebut (Andayani 2017). Perangkat lunak lainnya seperti PlagA-ware, PlagScan, iThenticate and Turnitin kini banyak digunakan perguruan tinggi untuk mendeteksi karya karya yang dihasilkan oleh para civitas akademika sebelum karya tersebut di publikasikan9.

Pada jurusan Aqidah Filsafat Islam setiap skripsi akan masuk ketahap pengecekan tindak plagiasi menggunakan aplikasi turnitin ini. Sesuai dengan peraturan jenderal pendidikan islam bahwa Batas toleransi dalam pembuatan karya ilmiah atau skripsi yang berbasis aplikasi deteksi plagiarisme, yang digunakan sebagai persyaratan kelulusan pada jenjang D-4 atau progam sarjana maksimal $25 \%^{10}$ sedangkan pada jurusan AFI batas plagiasinya juga mengikuti dan sesuai surat edaran tersebut.

Dalam proses pendeteksian turnitin mampu menemukan beberapa kesamaan jenis kalimat maupun kata, dimana hal tersebut dapat memberikan kontribusi yang cukup besar pada tindak peningkatan orsinalitas pada sebuah karya ilmiah yang dibuat para mahasiswa. Sebuah karya ilmiah dapat terdeteksi tingkat plagiatnya berdasarkan beberapa jenis dan cara penerapannya, dimana juga dapat di dianalis melalui turnitin maupun secara logika, meliputi:

a. Style Plagiarism, merupakan cara mengutip dengan menggunakan gaya dan bahasa sama, hanya saja diubah dalam bentuk kalimad dan paragraph yang berbeda.

b. Word Switch Plagiarism, adalah cara mengutip dengan hanya mengubah dan mengganti beberapa kalimad maupun kata, tanpa mencantumkan sumber referensinya. 
c. Idea Plagiarism, cara mengutip dengan mengambil sebuah ide maupun hasil dalam sebuah karya.

d. Metaphore Plagiarism, adalah jenis plagiarisme yang mengambil sebuah teori tanpa mencantumkan sumbernya, guna memperkuat hasil temuannya.

e. Self Plagiarism, mengutip karya sendiri yang telah diterbitkan terdahulu, tanpa mencantumkan sumber referensi diri sendiri.

Kemudian untuk menyiapkan mahasiswa yang berkompetensi dibidang riset dan penelitian jurusan aqidah filsafat islam menyediakan lembaga IJIR (Institute For Javanese Islam Research) yang sudah berdiri sejak tahun 2017. Lembaga IJIR didirikan sebagai sarana maupun laboratorium untuk mendorong berbagai skill dan kemampuan dibidang riset dan penelitian. IJIR dan jurusan AFI merupakan satu kesatuan yang tidak dapat dipisahkan, dimana AFI yang menyesuaikan dengan kurikulum dan IJIR instrument pendukungnya.

Beragam aplikasi cek plagiarism yang tersedia dengan berkembangnya teknologi saat ini, menjadikan jurusan akidah filsafat bukan hanya menggunakan deteksi plagiarism aplikasi turnitin saja, tetapi mereka juga menggunakan deteksi duplikasi checker. Sistem deteksi menggunakan duplikasi checker merupakan sistem online yang dapat diakses melalui website tanpa harus menggunakan biaya sama sekali.

Berdasarkan hasil pengamatan penulis hal tersebut seringkali terjadi apabila sebuah lembaga meminimalisir jumlah penggunaan turnitin sebab aspek biaya yang kurang. Sedangkan pada jurusan akidah filsafat islam mereka menggunakan dua deteksi dalam meningkatkan keorsinilitasan karya ilmiah utamanya skripsi disebabkan karena adanya dua instructor. Pada dasarnya setiap dosen ataupun lembaga di civitas academika yang sudah memiliki akses turnitin mereka dapat membuat kelas kelas yang mana dapat diakses mahasiswa secara mandiri. Namun hal lain yang perlu diperhatikan adalah jurusan akidah filsafat bukan hanya bergantung pada aplikasi ini dalam pemgecekan tindak plagiarism saja, mereka juga menggunkan felling yang berdasarkan kaidah kaidah dunia kepenulisan. Hal tersebut dapat terjadi dengan jumlah mahasiswa yang terbilang sedikit, sehingga dosen maupun pembimbing dapat melihat satu persatu karya secara detail. Pada dasarnya sebuah karya yang sudah maupun belum sesuai kaidah akan sangat terlihat mulai dari kata, kalimad bahkan susunan dan tata bahasanya. Sehingga hal tersebut menjadikan plagiarisme sudah Nampak terlihat. Apabila sebuah karya yang dikoreksi menggunakan felling terlihat kurang baik, jika di submit menggunakan turnitin akan sangat terlihat juga banyaknya prosentase kesamaannya atau tindak plagiasinya.

Adapun penggunaan Duplikasi checker antara lain:

a. File dapat dimasukkan melalui halaman website yang sudah disediakan, klik Choose file untuk uplod file yang akan dideteksi. File tersebut bisa berupa tex, txt, doc, docx, odt, pdf, rtf. Selain itu juga bisa cek plagiarism dengan menggunakan via Webpage URL.

b. Kemudian pada halaman Result, sudah akan muncul hasil prosentase tindak plagiarismenya. Namun presentase tindak plagiarisme belum terlihat secara detail,

c. Matched sources, pada halaman ini akan terlihat darimana sumber plagiasinya ditemukan, baik dari jurnal, maupun artikel web.

Beragam klinik menulis pun diselenggarakan guna mendapatkan hasil yang maksimal. Baik dalam kurun waktu setiap bulan maupun setiap membutuhkannya . Setiap lembaga perguruan tinggi akan mempunyai cara tersendiri untuk meningkatkan kualitas riset pada setiap mahasiswa, maupun akademisinya. Baik dengan beragam edukasi maupun dengan hadirnya aplikasi anti plagiat yang secara tidak langsung akan dapat meningkatkan keorsinalitasan sebuah karya 
ilmiah utamanya dikalangan mahasiswa. Berbagai universitas maupun institusi mampu menggunakan dan menghadirkan turnitin itu sendiri sebagai alur kebijakan untuk penerbitan sebuah karya ilmiah.

Pada jurusan ini untuk mengantisipasi plagiarisme mereka lebih menggunakan kebijakan revealing yakni terbuka dalam memberikan hasil pemeriksaan deteksi plagiarisme, dimana mereka akan mengecek jumlah similarity setiap karya mahasiswa sebagai syarat yang sudah ditentukan oleh institusi, kemudian memberikan hasil dari jumlah similarity nya kembali kepada mahasiswa agar adanya sebuah pembenahan.

Adapun antisipasi plagiarisme dapat dilakukan dengan konsep kebijakan seperti:

a. Integrating institutional policy (mengintegrasi kebijakan institusional)

b. Practice and tradition of asssement design (praktek dan tradisi desain penilaian)

c. Instructions of information for students (melakukan instruksi informasi untuk murid)

d. Revealing (terbuka dalam memberikan hasil pemeriksaan deteksi plagiarisme)

e. Suitable ways of penalties (institusi menetapkan hukuman yang disesuaikan dengan peraturan tentang anti plagiarisme) .

Berkembangnya ranah penelitian yang semakin pesat dalam dunia pendidikan, menjadikan berbagai lembaga institusi, jurusan maupun akademik lainnya memberikan semangat dan dukungan kepada mahasiswanya untuk terus berkembang dalam dunia penelitian. Bagi mahasiswa yang seringkali membuat tugas kuliah maupun artikel jurnal yang sesuai dengan kaidah kaidah kepenulisan sejak semester awal, maka secara tidak langsung mereka tidak akan merasa kesusahan dalam penyusunan tugas akhir kuliah atau skripsi. Namun sebelum hal tersebut terjadi, jarang kali mahasiswa saat ini memiliki keinginan sendiri untuk melakukan pembelajaran mandiri. Hal tersebut masih terlihat dengan beberapa pembuatan makalah ataupun pada tugas saat perkuliahan berlangsung, masih ditemui tindak plagiarisme. Maka dari hal tersebut sebuah karya ilmiah bukan hanya dengan menggunakan deteksi plagiarisme saja sudah cukup untuk meningkatkan keorsinilitasan sebuah karya, dan karya tersebut terbilang cukup baik.

Berdasarkan pengamatan penulis upaya tersebut juga dilakukan oleh jurusan akidah filsafat islam. Mereka melakukan pembelajaran tentang dunia kepenulisan yang sudah dilakukan sejak semester awal. Bukan hanya tercantum dalam kurikulum tetapi diluar kurikulum mereka juga seringkali mengadakan pembelajaran, baik tentang klinik menulis, penyusunan sebuah karya yang baik, proses pencarian referensi yang baik dan sebagainya yang terkait dengan dunia kepenulisan lainnya. Hal menarik lainnya lagi jurusan akidah filsafat islam juga menanamkan modal bahasa kepada mahasiswanya. Kegiatan itu terwujudkan dalam bentuk pembelajaran yang dilaksanakan setiap magrib pada ruang IJIR.

Pembelajaran atau kursus berbahasa inggris ini pada mulanya merupakan sebuah progam dari Fakultas Ushuluddin Adab dan Dakwah yang digagaskan secara langsung oleh dekan. Saat awal pembelajaran mulai berlangsung, secara keseluruhan mahasiswa berpartisipasi dan ikut serta dalam kursus berbahasa inggris, tetapi semakin hari berkurangnya mahasiswa yang tidak hadir dalam kegiatan tersebut. Namun khusus mahasiswa dari jurusan akidah filsafat dan islam ditekankan untuk tetap hadir. Upaya ini dilakukan agar dapat memaksimalkan orisinalitas sebuah karya sebelum di submit kedalam turnitin, karena turnitin hanya dapat melihat jumlah similarity nya saja tanpa melihat dari alur, isi konten ataupun logika dari sebuah karya ilmiah, hal ini merupakan salah satu dari kekurangan sistem turnitin itu sendiri meliputi Pencocokan konten isi yang tidak cerdas, turnitin tidak dapat mengenali formula matematis yang seharusnya tidak perlu di perhitungkan dalam pemeriksaan sebuah konten . 
Beragam kegiatan kepenulisan dilakukan agar memberikan bekal sekaligus tuntutan bagi mahasiswa untuk dapat membuat karya ilmiah secara baik dan benar. Terlebih juga Masih adanya jumlah similarity yang tinggi dalam karya ilmiah mahasiswa. Dalam proses analisis hasil skripsi admin juga akan perlu mengadakan sebuah analisa dimana kelemahan dari turnitin itu sendiri setiap teks masih dipukul rata oleh sistem. Setelah didapatkan hasil hendaknya format pdf tersebut dicetak, karena sudah ditemukannya beberapa tanda mulai dari sitasi dan tindak plagiasi yang ditemukan, dengan tanda berbagai warna. Warna pada hasil plagiasi tersebut akan berbeda, yang membedakan darimana pengambilan referensi tersebut diperoleh. Setelah melakukan pengecekan setiap kalimat yang berwarna, admin ataupun pihak yang melakukan analisa tinggal menyamakan dan melihat apakah kalimat tersebut kutipan atau tindak plagiasi. Apabila yang terblok warna merupakan sebuah kutipan, dengan sistematika yang benar, maka kesamaan tersebut sudah lazim terjadi. Namun apabila kalimat atau tulisan hanya terblog warna saja tanpa adanya sebuah kutipan, maka kutipan tersebut merupakan tindak plagiasi ataupun copy paste saja. Aplikasi turnitin juga akan memberikan blog warna terhadap:

a. Biblografi/ daftar pustaka, nama penulis, judul, tahun, penerbit, footnote maupun yang sejenisnya

b. Nama dari sebuah instansi, alamat, situs, alamat email, sesuatu hal yang sudah dipublish

c. Berbagai peraturan perundang undangan, pasal pasal dan ayat

d. Segala bentuk teori, penjelasn ataupun definisi yang sudah dipublish secara umum.

Seorang admin/ siapapun yang menganalisa dalam penggunaan turnitin, meraka perlu memperhatikan hal hal yang dapat menghindari beberapa hal yang meminimalisir berjalannya sistem seperti, unggahlah file karya ilmiah dengan format MS Word atau PDF saja, jangan melakukan penghapusan terhadap sebuah file yang sudah diunggah dalam turnitin (file yang dihapus oleh instructor mupun student hanya akan menghapus tampilan pada computer saja, dan akan tetap terlihat dalam file database) dan file yang diunggah bukan hasil dari sebuah scanner.

\section{Evaluasi Turnitin dalam Peningkatan Orsi- nalitas Karya Ilmiah}

Evaluasi merupakan tahapan akhir dalam proses dan kegiatan implementasi turnitin ini, dalam pengurangan tindak plagiarisme untuk memaksimalkan keorsinilitasan karya ilmiah. Evaluasi ini merupakan tombak akhirnya sebuah implementasi baik dari tahapan formulasi maupun pelaksanaan. Evaluasi wajib dilakukan setiap kali lembaga maupun organisasi melakukan sebuah proses ataupun kegiatan. Dengan kegiatan ini sebuah lembaga akan mengetahui tingkat keberhasilan, atau tingkat kegagalan bisa jadi kelemahan dan kekurangan yang menyebabkan kegiatan berlangsung secara baik ataupun tidaknya.

Pada jurusan akidah filsafat islam turnitin hanya digunakan untuk melengkapi syarat dan peraturan saja untuk mengetahui prosentase tindak plagiarisme, dan pada dasarnya hal utama yang dapat meningkatkan keorsinalitasan sebuah karya ilmiah maupun tugas akhir adalah kemampuan mahasiswa dalam melakukan kegiatan riset maupun penelitian. Dalam penggunaannya aplikasi turnitin sudah digunakan sekitar satu tahun, tentu terdapat berbagai kendala yang terjadi, mulai dari kurangnya akses dari instructor, dana maupun sistem pendukung lainnya. Selain itu masih adanya karya ilmiah mahasiswa yang memiliki tingkat similarity tinggi. Maka dari itu dalam tahap evaluasi akses turnitin tidak digunakan dengan baik, karena dalam data statistik akun jurusan AFI terbilang tidak aktif.

Penggunaan aplikasi turnitin selalu terlihat dalam database administrator utama, yakni tentang aktif tidaknya dalam menggunakan aplikasi tersebut. Namun untuk statistik maupun jumlah 
file yang dicek dan disubmit pada aplikasi turnitin tidak dapat terlihat dan terdeteksi oleh administrator. Berdasarkan hasil wawancara terhadap administrator untuk penggunaan turnitin oleh user jurusan Aqidah Filsafat Islam terbilang kurang aktif .

Berdasarkan hasil penelitian, aplikasi turnitin dapat mengurangi tindak plagiarisme, dimana deteksi ini digunakan sebagai syarat dari sebuah tugas akhir skripsi maupun karya ilmiah. Namun untuk memaksimalkan keorsinalitasan sebuah karya, jurusan Aqidah filsafat Islam bukan hanya menggunakan deteksi plagiarisme saja, tetapi mereka juga menekankan sebuah kemampuan riset dan penelitian melalui beragam pendidikan baik yang ada di dalam kurikulum perkuliahan maupun di luar kurikulum perkuliahan. Kegiatan yang seringkali dilaksanakan juga dapat membuahkan hasil, tetapi juga masih ditemukannya mahasiswa yang kurang mumpuni, merasa ketakutan dan tingkat similarity yang tinggi dalam melakukan bidang riset ataupun penelitian dikarenakan semakin ketatnya peraturan dalam pembuatan karya ilmiah jurnal maupun tugas akhir skripsi.

Dengan dibuatnya kurikulum lama yang bertujuan lebih menekankan lulusan mahasiswa jurusan aqidah filsafat islam menjadi peneliti yang handal, dimana mereka sudah sering mendapatkan pendidikan di bidang penelitian dan riset. Secara tidak langsung mulailah bermunculan juga, terdapat mahasiswa yang karya akhir skripsinya dapat disubmit ke dalam jurnal. Mahasiswa sudah mampu menerbitkan karya skripsinya ke jurnal internal kampus IAIN Tulungagung seperti jurnal kontemplasi dan jurnal episteme, ataupun jurnal tentang gender. Dengan hasil yang telah dicapai pihak jurusan sudah mendapatkan hasil yang cukup baik, meskipun masih juga ditemukan jumlah similarity yang tinggi dalam pembuatan karya ilmiah. Kemudian dari kurikulum tersebut pihak ketua jurusan masih menganggap kurang maksimal dalam pembuatan progam dibidang riset dan penelitian. Maka jurusan mengadakan dan mengusulkan kurikulum baru yang dilangsungkan dalam kegiatan di perkuliahan maupun diluar perkuliahan.

Tahapan evaluasi jurusan aqidah filsafat islam belum dilakukan secara maksimal, Selain itu dalam pengecekan tindak plagiarisme dan memaksimalkan keorisinalitasan sebuah karya mereka akan lebih mudah mendapati hasil menggunakan metode felling, hal tersebut dilakukan sebab jumlah karya akhir mahasiswa dalam hitungan 7-15 skripsi. sedangkan turnitin hanya digunakan sesudah metode tersebut. Namun dengan metode feeling hanya dapat menyimpulkan tindak plagiarisme dari struktur bahasa saja, dan perlu waktu lama jika harus menemukan dari mana sitasi yang digunakan. Berbeda dengan menggunakan aplikasi deteksi plagiarisme seperti turnitin maupun duplicat checker, mereka akan dengan mudah mengetahui hasil sitasi, bahkan tingkat prosentase similarity.

Kemudian dalam akses turnitin, mahasiswa belum mampu untuk mengakses sendiri karena admin tidak menggunakan sebuah kelas untuk bisa akses dan melakukan pengecekan sendiri. Seharusnya layanan turnitin juga disediakan oleh pihak dosen ataupun perpustakaan, sehingga mahasiswa dalam melakukan akses tidak bergantung pada satu admin. Jika berdasarkan hal tersebut akan memakan biaya yang cukup besar dengan akses turnitin secara mandiri, hendaknya pihak jurusan maupun perpustakaan menyediakan akses turnitin secara mandiri bagi mahasiswa akhir saja dengan dibatasinya penggunaan softwere deteksi plagiarisme tersebut.

Akses turnitin pada dasarnya diberikan akses pada student sehingga memudah pustakawan ataupun dosen untuk menyimpulkan dalam pengurangan tindak plagiat. Adanya pemberian akses secara langsung terhadap student dapat meminimalisir tindak plagiarisme dan meningkatkan keorsinalitasan sebuah karya . Keunggulan dari pengecekan atau pemeriksaan menggunakan 
perangkat lunak turnitin menurut Jack Brazel ( Asia DevelopmentManager Turnitine) diantaranya adalah terhubung dengan lebih 45.000.000.000 website online, lebih dari 337.000.000 esai akademis, lebih dari 130.000 .000 artikel atau publikasi ilmiah, oleh karena itu Jack Brazel menyimpulkan turnitin sangat cocok untuk mendeteksi plagiarisme karya ilmiah mahasiswa .

\section{Kesimpulan dan Saran}

Implementasi turnitin yang dilakukan pada jurusan AFI melalui tahapan proses formulasi, pelaksanaan dan Evaluasi belum berlangsung secara maksimal. Dalam berbagai kegiatan tersebut sebuah lembaga akan dapat memperoleh hasil yang maksimal dalam penggunaan sebuah aplikasi, maupun sebuah progam lainnya. Jurusan akidah filsafat islam merupakan salah satu jurusan yang menggunakan deteksi turnitin sebagai softwere yang dapat meningkatkan keorisinalitasan sebuah karya ilmiah utamanya skripsi dan jurnal. Tahapan awal atau formulasi sebelum pelaksanaan, hendaknya menyiapkan perlengkapan pendukung yang dibutuhkan, kebijakan ataupun peraturan, visi misi dan juga siapa saja yang memberi akses dan mendapatkan akses, dalam tahap ini perpustakaan pusat IAIN Tulungagung juga memiliki peran penting dalam pemberian pelatihan turnitin. Selanjutnya pada tahap pelaksanaan akses turnitin didapatkan secara langsung dari perpustakaan, kemudian hanya ada seorang instruktor saja tanpa adanya sebuah kelas student dalam akses turnitin. Turnitin dapat digunakan dengan cara yang sudah ada mulai dari memasukkan akun hingga tahap terakhir dengan mendapatkan hasil. Selain itu untuk mengantisipasi tindak plagiarisme, adanya sebuah kebijakan revealing yakni terbuka terhadap hasil plagiarisme. Kemudian pada tahap evaluasi disebutkan masih adanya mahasiswa yang karyanya memiliki jumlah similarity yang masih tinggi meskipun sudah diadakan beragam pelatihan menulis dan sebagainya. Selain itu dari berbagai lembaga dan jurusan yang mengakses turnitin, jurusan Aqidah Filsafat masih terbilang user yang kurang aktif dalam penggunaannya.

\section{Referensi}

Akdon. (2007). Strategic Management for Educations Management (Manajemen Strategi Untuk Manajemen Pendidikan). Bandung: Alfabeta.

Anam, Khairul. (2017). "Tutorial Cek Plagiasi Dengan Turnitin."

Andayani, Ulpah. (2017). "Penggunaan Software Turn It In Untuk Mendeteksi Tindakan Plagiarisme," 33-40. http://journal.uinjkt.ac.id.

Baker, Russell K, Barry Thornton, and Michael Adams. 2008. "An Evaluation Of The Effectiveness Of Turnitin.Com As A Tool For Reducing Plagiarism In Graduate Student Term Papers" 4 (9): 1-4.

Islam, Direktur Jenderal Pendidikan. (2017). "Keputusan Direktur Jenderal Pendidikan Islam Nomor 7142 Tahun 2017 Tentang Pencegahan Plagiarism Di Perguruan Tinggi Keagamaan Islam."

Kepegawaian, Badan. (2015). "Pedoman Penyusunan Karya Tulis/ Karya Ilmiah Assessor Sumber Daya Manusia Aparatur."

Machali, A Hidayat dan I. (2010). Pengelolan Pendidikan. Bandung: Pustaka Educa.

Manunggal, Yonathan Cahyo, Lydia Christiani, Program Studi, S- Perpustakaan, Fakultas Ilmu Budaya, Universitas Diponegoro, Jl Prof Soedarto, Kampus Undip Tembalang, and Dian Nuswantoro. (2018). "Pemanfaatan Sistem Deteksi Plagiarisme Menggunakan Turnitin (® Pada Jurnal Mahasiswa Universitas Dian Nuswantoro." https://ejournal3. undip.ac.id.

Mulyasa, E. (2009). Implementasi Kurikulum Tingkat Satuan Pendidikan Kemandirian Guru Dan Kepala SEkolah. Jakarta: PT. Bumi Aksara.

Pambayun, Kuncoro G. (2018). "Menganalisa 
Hasil Pemeriksaan Turnitin Untuk Dosen Pembimbing LA/Skripsi Praja IPDN." In . Jawa Barat: Pusat Perpustakaan IPDN Jatinangor. http://lib.pdn.ac.id.

Prabowo, Aan. (2018). "Peran Pustakawan Dalam Literasi Layanan Turnitin Kepada Pemustaka Di Universitas Dian Nuswantoro" 6 (2): 419-38. https://ejournal3.undip.ac.id.

Sanjaya, Wina. (2008). Perencanaan Dan Sistem Desain Pembelajaran. Jakarta: Kencana Persada Media Group.

Sinaga, Steven Yehezkiel. (2019). "Penggunaan Aplikasi Turnitin Sebagai Sarana Cek Plagiarisme Dalam Layanan Perpustakaan Uni- versitas Ukrida" 2: 123-31. http://journal2. um.ac.id.

Turnitin LCC. (2018)a. "The Effectiveness of Turnitin in Higher Education,." http://go.turnitin. com/paper/effectiveness-turnitin-higher-educations.

. (2018)b. "Turnitin." www. Turnitin. com.

Usman, Nurudin. (2002). Konteks Implementasi Berbasis Kurikulum. Jakarta: Teras.

Wheelen, Thomas L dan J David, Hunger. (2012). Strategik Management and Bussiness Policy Achieving Sustainability. Ed. 9. Prentice Hall.

Yulis, Rama. (2006). Ilmu Pendidikan Islam. Jakarta: Kalam Mulia. 